\title{
EFFECT OF TIME OF SOWING AND PLANT SPACING ON BROCCOLI PRODUCTION
}

Hossain MF, Ara N, Uddin MR, Dey S and Islam MR

Bangladesh Agricultural Research Institute, Gazipur, Bangladesh

Accepted : 14 october 2011

\begin{abstract}
A field experiment was conducted at Agricultural Research Station, BARI, Thakurgaon during rabi season, 2009/10 to find out the optimum time of sowing and plant spacing on broccoli production. Three sowing time viz. (i) 1 October, (ii) 15 October and (iii) 30 October and three plant spacing viz. (i) $60 \mathrm{x}$ $40 \mathrm{~cm}$, (ii) $60 \times 50 \mathrm{~cm}$ and (iii) $60 \times 60 \mathrm{~cm}$ were included in the study. Yield and yield contributing characters were significantly influenced by the treatments. 1 October sowing produced the highest yield (21.39 t/ha) and 30 October sowing produced the lowest yield (13.6t/ha) of broccoli. On the other hand, closer spacing $(60 \times 40 \mathrm{~cm})$ produced the highest yield $(18.8 \mathrm{t} / \mathrm{ha})$ which was statistically similar to $60 \times 50 \mathrm{~cm}$ (17.6t/ha) and lowest yield (16t/ha) was obtained from $60 \times 60 \mathrm{~cm}$ spacing. 1 October sowing and $60 \mathrm{x}$ $40 \mathrm{~cm}$ plant spacing combination produced the highest yield $(22.5 \mathrm{t} / \mathrm{ha}$ ) which was statistically similar to 1 October sowing and $60 \times 50 \mathrm{~cm}$ plant spacing $(21.9 \mathrm{t} / \mathrm{ha})$ and the lowest yield $(12.8 \mathrm{t} / \mathrm{ha})$ was produced from 30 October sowing and $60 \times 60 \mathrm{~cm}$ plant spacing combination.
\end{abstract}

Key words: Broccoli Production, Planting Time and Spacing, Cruciferacea

\section{INTRODUCTION}

Broccoli (Brassica oleracea var italica) (Cruciferae) is a biannual and herbaceous winter vegetable crop in Bangladesh. Broccoli, originated from west Europe (Prasad and $\mathrm{Ku}-$ mar 1999) has now been distributed in both the sub tropical and tropical areas like Bangladesh. The crop is considered as a commercial crop in India (Nonnecke 1989). Broccoli is planted in the winter season in Bangladesh. Flower heads develop relative to ambient temperatures (15$20^{\circ} \mathrm{C}$ ), and in the heat of summer, broccoli heads matured and produced flowers (Lorenz and Maynard 1988). The temperature in Bangladesh remains fairly high up to mid October and gradually goes down in mid December. This cool period extends up to mid February. The temperature increase sharply thereafter. It is therefore important to study the effect of planting time for achieving optimum growth and yield of broccoli (Das et al. 2000). Higher plant population reduced head size, lower average marketable head weight and delay maturity (Khan et al. 1991). Its cultivation in Bangladesh has not extended due to the lack of awareness regarding its nutritive value and appropriate method of planting including planting time and spacing. Therefore, the present study was undertaken to identify the best sowing time and plant spacing.

\section{MATERIALS AND METHODS}

The research was carried out at Agricultural Research Station, Thakurgaon during rabi season $2009 / 10$ as a factorial experiment, laid out in RCB design with 3 replications (Table 1). The unit plot size was $10 \mathrm{~m} \times 1.2 \mathrm{~m}$. The amounts of fertilized applied $(\mathrm{kg} / \mathrm{ha})$ as follows: Urea, 260: TSP, 150: MoP, 100: Gypsum, 80; Zn, 1.5; Boron, 2. Total amount of cow dung, TSP, gypsum, zinc sulphate and boric acid were applied in the plot during final land preparation. Urea and MoP were applied in three equal installments at 15,30 and $45 \mathrm{~d}$ after planting. Irrigations were done when necessary. Three weeding was also done after planting.

Ten plants were selected randomly for data collection. Immature and developed broccoli heads from each treatment were harvested at 7$10 \mathrm{~d}$ interval throughout the harvesting season. The number of leaves per plant, days to first harvest, head size, single head weight, Main head yield, lateral head yield and total yield were recorded. The collected data were analyzed statistically and the means were separated by LSD.

\footnotetext{
*Corresponding author: faruk_bari@yahoo.com
} 
Table 1: Treatments tested

\begin{tabular}{ll}
\hline Factor A & Factor B \\
Time of sowing & Plant spacing \\
\hline 1 October & $60 \times 40 \mathrm{~cm}$ \\
15 October & $60 \times 50 \mathrm{~cm}$ \\
30 October & $60 \times 60 \mathrm{~cm}$ \\
\hline
\end{tabular}

\section{RESULTS AND DISCUSSION}

\section{Effect of time of sowing on broccoli produc- tion}

Yield and yield contributing characters of broccoli were significantly influenced by the time of sowing (Table 2). Minimum days required to first harvest of broccoli head was recorded in 30 October sowing while 1 October sowing required maximum period of $90.4 \mathrm{~d}$. Maximum length and diameter of broccoli head were obtained from 1 October sowing. On the other hand, 15 October sowing produced the longest broccoli head and 30 October sowing produced minimum head diameter. The highest single head weight was recorded from 1 October sowing and the lowest single head weight was recorded from 30 October sowing. Being a thermo sensitive plant, the early planted plant received comparatively low temperature during vegetative growth which produced bigger sized head. The main head yield and lateral head yield of broccoli were significantly influenced among the three sowing time. 1 October sowing produced the highest main head yield and lateral head yield and 30 October sowing produced the lowest main head yield and lateral head yield. The report of Lawande et al. (1988) and Tewary et al. (1987) are the agreement with the present findings.

\section{Effect of spacing on broccoli production}

Most of the parameters were not significant for plant spacing. Only single head weight, min head weight and total yield were significantly affected by the treatment (Table 3 ). The maximum single head weight was measured from

Table 2. Effect of time of sowing on yield of broccoli

\begin{tabular}{|c|c|c|c|c|c|c|c|}
\hline $\begin{array}{l}\text { Time } \\
\text { of sow- } \\
\text { ing }\end{array}$ & $\begin{array}{l}\text { No. of } \\
\text { - leaves } \\
\text { /plant }\end{array}$ & $\begin{array}{l}\text { fDays } \\
\text { s to firs } \\
\text { har- } \\
\text { vest }\end{array}$ & $\begin{array}{l}\text { Lengt } \\
\text { th of } \\
\text { head } \\
(\mathrm{cm})\end{array}$ & $\begin{array}{l}\text { Diame } \\
\text { ter of } \\
\text { head } \\
(\mathrm{cm})\end{array}$ & $\begin{array}{l}\text { - Singl } \\
\text { head } \\
\text { wt. (g }\end{array}$ & $\begin{array}{l}\text { Main } \\
\text { head } \\
\text { )yield } \\
\text { (t/ha) }\end{array}$ & $\begin{array}{l}\text { Lateral } \\
\text { head } \\
\text { yield } \\
(\mathrm{t} / \mathrm{ha})\end{array}$ \\
\hline 1 Oct. & 19.8 & 90.4 & 22.6 & 22.9 & 638 & 16.7 & 4.7 \\
\hline 15 Oct. & 20.0 & 83.1 & 15.8 & 18.8 & 478 & 15.0 & 2.5 \\
\hline 30 Oct. & 19.4 & 80.2 & 16.7 & 16.2 & 347 & 12.2 & 1.3 \\
\hline $\mathrm{CV}(\%)$ & 6.5 & 3.7 & 8.2 & 8.2 & 14 & 12.0 & 9.8 \\
\hline LSD & - & 21.4 & 4.5 & 4.5 & 240 & 6.2 & 3.2 \\
\hline
\end{tabular}

Table 3. Effect of spacing on yield of broccoli

Time of No. of Days Lengt Diame-Single Main Latsowing leaves to firsth of ter of head head eral /plant har- head head wt. (g)yield head vest $(\mathrm{cm}) \quad(\mathrm{cm}) \quad(\mathrm{t} / \mathrm{ha})$ yield (t/ha)

\begin{tabular}{llllllll}
\hline $60 \times 40 \mathrm{~cm}$ & 19.4 & 85.7 & 18.8 & 18.6 & 441 & 16.3 & 2.5 \\
60x50cm & 19.7 & 84.6 & 18.0 & 19.3 & 479 & 14.7 & 2.0 \\
$60 \times 60 \mathrm{~cm}$ & 20.1 & 83.5 & 18.2 & 20.0 & 543 & 12.8 & 3.0 \\
$\mathrm{CV}(\%)$ & - & - & - & - & 14.0 & 12.0 & - \\
$\mathrm{LSD}\left({ }_{0.05}\right)$ & - & - & - & - & 75.9 & 6.1 & -
\end{tabular}

$60 \mathrm{~cm} \times 60 \mathrm{~cm}$ and the minimum single head weight was measured from $30 \mathrm{~cm}$ x $30 \mathrm{~cm}$. Food accumulation was maximum in the plant which was grown at wider spacing. As a result the head was large sized and weight became maximum. The present results are partially similar with results obtained by Griffith and Carling (1991). However, the main head yield of broccoli was significantly different from one treatment to another. $60 \mathrm{~cm} \times 40 \mathrm{~cm}$ plant spacing produced the highest main head yield and $60 \mathrm{~cm} \times 60 \mathrm{~cm}$ plant spacing produced the lowest main head yield. Similar results had got by Pornsuriya et al. (1997). Main head yield and total yield of broccoli followed the same trend in response to plant spacing. Increasing the plant number per plot decreased the head size but increased the yield (Nassar et al. 1972)

\section{Combined effect of time of sowing and plant spacing on broccoli production}

Treatment combination of time of sowing and plant spacing had significant effect on yield and yield contributing characters of broccoli production (Table 4). Combination of 30 Octo-

Table 4. Combined effect of time of sowing and spacing on broccoli production

Treatment No. of Days Lengt Dame-Single Main Latcombina- leaves to firsth of ter of head head eral tion (cm) /plant har- head head wt. (g)yield head

\begin{tabular}{llllllll} 
& & vest & $(\mathrm{cm})$ & $(\mathrm{cm})$ & & $(\mathrm{t} / \mathrm{ha})$ & $\begin{array}{l}\text { yield } \\
(\mathrm{t} / \mathrm{ha})\end{array}$ \\
\hline $1 \quad 60 \times 40$ & 19.0 & 91.7 & 23.7 & 26.7 & 607 & 18.3 & 4.1 \\
Oct60x50 20.0 & 90.4 & 22.3 & 23.0 & 644 & 17.3 & 4.5 \\
$60 \times 60$ & 20.3 & 89.3 & 21.7 & 23.0 & 663 & 14.3 & 5.3 \\
$1560 \times 40$ & 20.0 & 83.7 & 16.3 & 18.0 & 410 & 16.9 & 2.4 \\
Oct60x50 19.7 & 83.0 & 15.3 & 18.7 & 546 & 15.1 & 2.3 \\
$60 \times 60$ & 20.3 & 79.6 & 15.7 & 19.7 & 580 & 12.6 & 2.8 \\
30 60x40 19.3 & 81.6 & 16.3 & 15.0 & 307 & 13.4 & 1.1 \\
Oct60x50 19.3 & 80.3 & 17.3 & 16.3 & 346 & 11.7 & 1.4 \\
$60 \times 60$ & 19.7 & 78.7 & 17.3 & 17.3 & 387 & 11.4 & 1.3 \\
CV (\%) - & 3.75 & 8.2 & 8.19 & 14.0 & 12.0 & 9.8 \\
LSD(0.05) - & 11.49 & 2.8 & 2.97 & 128.6 & 3.31 & 1.6 \\
\hline
\end{tabular}




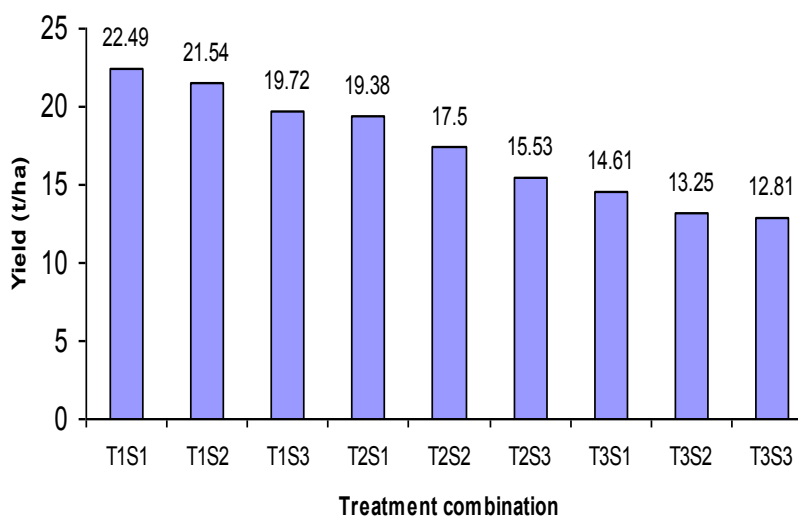

Fig.1. Combined effect of time of sowing and plant spacing on yield of broccoli

ber sowing and $60 \mathrm{~cm} \times 60 \mathrm{~cm}$ plant spacing required the minimum days to first harvest of broccoli and 1 October sowing and $60 \mathrm{~cm} \mathrm{x}$ $40 \mathrm{~cm}$ plant spacing required the maximum days to first harvest. Size of broccoli head also significantly different from combination to combination. Maximum length and diameter of broccoli head was measured from the treatment combination of 1 October sowing and $60 \mathrm{~cm} \mathrm{x}$ $40 \mathrm{~cm}$ plant spacing. Main head yield, lateral head yield and total yield were also significant. The highest main head yield was obtained from the treatment combination of 1 October sowing and $60 \mathrm{~cm} \times 40 \mathrm{~cm}$ plant spacing. The lowest main head yield was recorded from the combination of 30 October sowing and $60 \mathrm{~cm} \times 60 \mathrm{~cm}$ plant spacing.

\section{CONCLUSION}

Results of the present study revealed that 1 October to 15 October seed sowing is the optimum time for broccoli production. Before 1 October, seed sowing was not possible because of rainfall in Bangladesh. Besides, $60 \mathrm{~cm} \mathrm{x}$ $40 \mathrm{~cm}$ and $60 \mathrm{~cm} \times 50 \mathrm{~cm}$ plant spacing increased statistically similar yield of broccoli. Further studies are needed to optimize the specific time and plant spacing for the highest yield of broccoli.

\section{REFERENCES}

Das J, Phookan DB and Gautam BP 2000 Effect of levels of NPK and plant density for curd production of early cauliflower (Brassica oleracea var. botrytis) cv. Pusa Katki. Haryana J. Hort. Sci., 29(3): 265-266.
Decoteau DR 2000 Vegetable crops. Upper Rever Compani. New Jersey, U.S.A.

Griffith M and Carling DE 1991 Effects of plant spacing on broccoli yield and hollow stem in Alaska. Canadian J. Plant Sci.,71(2): 579-585.

Khan BA, Shilling PG, Brusewitz GH and Mcnew RW 1991 force to shear the stalk, stalk diameter and yield of broccoli in response to nitrogen fertilization and within row spacing. J. Amer. Soc. Hort. Sci., 116(2): 222-227.

Lawande KE, VA Khaire and DP Bhore 1988 Effect of sowing date on yield of broccoli. J. Maharashtra Agril. Univ., 13(1): 100-110.

Lorenz OA and Maynard DM Knott's Handbook forVegetable Growers. Third Edition. New York: John Wileyand Sons, Inc., 1988.

Nassar SH, M El-Sherbni, Abdelgawad MG and Nasr MS 1972 Effect of some factors on cauliflower seed production. Agric. Res. Rev., 50(4): 109-119.

Nonnecke IL 1989 Vegetable Production. Vein Nostrand Reinhold, New york.

Prasad S and Kumar U1999 Principle of Horticulture. Agrobotanica, 4E 176. J. N. Vyas Nagar, India. P. 6.

Pornsuriya $\mathrm{P}$, Pornsuriya $\mathrm{P}$ and Teeraskulchon $\mathrm{S}$ 1997 Studies on broccoli production in Chonburi Province, Thailand. Kasetsart J. Natural Sci., 32 (4): $81-85$

Rangkadilok N, Nicolas ME, Bennete RN, Eagling DR, Premier RR and Tailor WJ 2004 The effect of sulpher fertilizer on glucoraphanin levels in broccoli ( $B$. oleracea L var. italica) at different growth stages. J. Agric. Food Chem., 52:2632-9.

Rangkadilok N, Nicolas ME, Bennete RN, Premier RR, Eagling DR and Tailor WJ 2002 Determination of sinigrin and glucoraphanin in Brassica species using a simple extraction method combined with iron-pair HPLC analysis. Scientia Horticulture, 96: 27-41.

Salunkhe DK and Kadam SS 1998 Handbook of Vegetable Science and Technology: Production, Storage, and Processing, $1^{\text {st }}$ edition. Marcel Dekker, Inc. Madison Avenue, New York, USA.

Talalay P and Fahey JW 2001 Phytochemicals from cruciferous plants protect against cancer by modulating carcinogen metabolism. American Soc. Nutr. Sci., 23:3027-33.

Tewary RN, Gill SH and Ram S 1987 Influence of different planting times on gead shape in broccoli. Prog. Hort., 8(4): 35.38.

Yoldas F, Ceylan S, Yagmur B and Mordogan N 2008 Effect of nitrogen fertilizer on yield quality and nutrient content in broccoli. J. Plant Nutr., 31: 1333-43. 